Published in final edited form as:

J Org Chem. 2002 October 4; 67(20): 6911-6915.

\title{
Rapid Syntheses of Benzopyrans from o-OBOC Salicylaldehydes and Salicyl alcohols: A Three-Component Reaction
}

\author{
Ryan M. Jones, Carolyn Selenski, and Thomas R. R. Pettus* \\ Department of Chemistry and Biochemistry, University of California, Santa Barbara, California \\ 93106-9510
}

\section{Abstract}

The Diels-Alder reactions of $o$-quinone methides generated from OBOC-salicylic aldehydes and alcohols are described, allowing for the synthesis of various substituted benzopyrans. The low temperatures employed for this procedure enable high diastereoselectivity in reactions with $\beta$ substituted $o$-quinone methides.

\section{Introduction}

The benzopyran "chroman" nucleus is found in a variety of therapeutic agents. ${ }^{1}$ Our interest in structurally diverse benzopyrans such as the COX-2 inhibitor diinsininol $\mathbf{1}^{2}$ and the helicase inhibitor heliquinomycin $2^{3}$ prompted us to consider methods for rapidly fashioning benzopyrans containing ample functionality. We recently described a new facile method for generating $o$-quinone methides in situ from $o$-OBOC salicylic aldehydes and alcohols and examined their reactivity in 1,4-conjugate additions. ${ }^{4}$ We now report the extension of this procedure for the construction of a diverse range of benzopyrans.

$o$-Quinone methides ( $o$-QMs) are extremely reactive, undergoing dimerization or trimerization ${ }^{5}$ in the absence of a nucleophile or electron-rich alkene. To account for this reactivity, the $o$-QM concentration must be kept low throughout the reaction. Therefore, various methods have been engineered to generate these species in the presence of the nucleophile necessary for the next reaction, allowing for the generation and immediate consumption of the $o$-QM. Naturally, the first applications involved intramolecular cyclization motifs. ${ }^{6}$ There are only a few accounts of successful intermolecular applications. ${ }^{7}$ Most are complicated by the preparation of the $o$-QM because they rely on high temperatures or powerful Lewis acids for their generation; therefore, the range of nucleophiles is severely limited as is the ultimate diastereoselectivity in $[4+2]$ cycloadditions.

Building upon an account of McLoughlin, ${ }^{8}$ we reported that $o$-OBOC salicylaldehydes and salicyl alcohols could lead to $\beta$-substituted and $\beta$-unsubstituted $o$-QMs, respectively, at low temperature upon the addition of an organometallic reagent (Scheme 1). ${ }^{4 a}, \mathrm{~b}$ Herein, we report our observations regarding the generation of $\mathbf{3}$ and $\mathbf{4}$ and their performance in subsequent inverse electron demand [4+2] cycloaddition reactions with various styrenes, enol ethers, enamines, imines, and heteroaromatics. As can be seen, the mild low-temperature procedure allows three components to be combined in a single pot, thereby producing a vast array of assorted benzopyrans.

pettus@chem.ucsb.edu.

Supporting Information Available: Spectral data for compounds 5-16. This material is available free of charge via the Internet at http://pubs.acs.org. 
To generate the $o$-QM from alcohol 3 or aldehyde $\mathbf{4}$, an organomagnesium reagent is added. For more precise control, an organolithium reagent is added, followed by the addition of $\mathrm{MgBr}_{2} \cdot \mathrm{OEt}_{2}$. In both cases, the addition results in a metal alkoxide intermediate that attacks the neighboring $\mathrm{BOC}$ residue. A migration ensues resulting in a phenoxide that, if $\mathrm{M}=\mathrm{Mg}$, undergoes $\beta$-elimination of the benzylic OBOC residue to form an $o$-QM. When $\mathrm{M}=\mathrm{Li}, \beta$ elimination does not occur until addition of $\mathrm{MgX}_{2}$ or $\mathrm{LiX}$, which both act as Lewis acid catalysts. When the $o-\mathrm{QM}$ is generated in the presence of an electron-rich alkene, a diastereoselective [4+2] cycloaddition ensues to afford primarily a cis 1,3-substituted benzopyran.

\section{Results and Conclusions}

As shown in Table 1, the process proves quite general and far more convenient than previous methods involving $o$-QMs. Since the cycloaddition occurs between -78 and $-10{ }^{\circ} \mathrm{C}$ it is much more sensitive to electronic effects and proceeds with better stereoselectivity than previous methods. Moreover, the pliable nature of the procedure allows many substituents to be introduced at the benzylic carbon of the benzopyran nucleus through variations in the organometallic reagent used to initiate formation of the $o$-QM. Although non- $\beta$-substituted $o$ QMs appear to be more reactive than their $\beta$-substituted counterparts, $\beta$-substituted $o$-QMs generated in this manner still undergo reaction with both activated and inactivated alkenes in respectable yields. For example, styrene (17) adds to the $o$-QM generated from alcohol $\mathbf{3}$ by the addition of $t-\mathrm{BuMgCl}(\mathbf{2 6})$ to produce 5 in $50 \%$. On the other hand, addition of $\mathbf{1 7}$ to the $o$-QM generated by the addition of $\mathrm{MeMgCl}(31)$ to aldehyde 4 proceeds in only $27 \%$. In both of these examples, styrene (17) was used as the solvent to maximize the percent yield.

More reactive alkenes proceed with better stereoselectivity and require fewer molar equivalents relative to the $o$-QM. For example, ethyl vinyl ether (10 equiv) adds to the various $\beta$-substituted $o$-QMs generated from 4 (entries 3-5, Table 1) with a greater than 50:1 preference in the corresponding cis:trans ratio. The cis-2-ethoxy-4-phenylbenzopyran (7), the cis-2-ethoxy-4vinylbenzopyran (8), and the cis-2-ethoxy-4-(dimethylphenylsilyl)-benzopyran (9) are assembled from three components: an aldehyde, an enol ether, and the necessary organometallic reagents (cf. 28, 29, and $\mathbf{3 0}^{9}$ ). Although more congested enol ethers, such as those disubstituted in a vicinal or geminal fashion, prove to undergo less stereo-selective cycloadditions, the results are still quite satisfactory. Addition of Grignard $\mathbf{3 1}$ to aldehyde $\mathbf{4}$ in the presence of dihydropyran $(\mathbf{1 9}, 10$ equiv) proceeds to 10 with a $24: 1$ ratio of cis:trans isomers. The enol ether 20, 10 which presents two groups ( $-\mathrm{OMe}$ and $-\mathrm{Ph}$ ) capable of secondary orbital interactions, affords $\mathbf{1 1}$ with 4:1 selectivity, apparently favoring the endo approach of the phenyl residue.

Other noteworthy adducts include the combination of $o$-QMs with enamines 21-23 and imine 24 (entries 8-11, Table 1). The reactions proceed quite rapidly in good overall yield. For example, the $E$-configured vinylogous amide $21^{11}$ smoothly undergoes cycloaddition with the $o$-QM that is generated by the addition of $\operatorname{MeLi}(\mathbf{3 2})$ to aldehyde $\mathbf{4}$ followed by the addition of $\mathrm{MgBr}_{2} \cdot \mathrm{OEt}_{2}$. However, the initial cycloadduct proves to be unstable and the pyrrolidine is eliminated upon chromatography to yield the chromene 12. In a somewhat analogous fashion, the cycloadduct that emerges from addition of enamine $\mathbf{2 2}^{12}$ to the same $o$-QM undergoes pyrrolidine hydrolysis and hydrate collapse upon chromatography to produce the ketone $\mathbf{1 3}$. On the other hand, cycloaddition of trisubstituted enamine $\mathbf{2 3}$ with the $\beta$-vinyl substituted $o$ QM, generated by addition of vinyl Grignard 29 to aldehyde 4 , proceeds to the apparently more stable cycloadduct 14. However, stirring 14 with acid does lead to the corresponding chromene by elimination of the morpholine residue. The reaction between imine 24 and the $o-\mathrm{QM}$ generated by addition of $\mathbf{3 1}$ to aldehyde $\mathbf{4}$ proceeds to $\mathbf{1 5}$ in the highest yield of all $2 \pi$ donors examined. Interestingly, the stereochemistry is trans, suggesting an exo-oriented combination 
of reactants. Most likely, however, the cis isomer can undergo an intramolecular equilibration to the more thermodynamically stable trans conformation, a process facilitated by the Lewis acid $\mathrm{MgBr}_{2}$ (Figure 2). Generation of an $o-\mathrm{QM}$ in the presence of a heterocyclic aromatic also yields benzopyrans in high regioselectivity and diastereoselectivity. The addition of methyl Grignard 31 to aldehyde $\mathbf{4}$ in the presence of furan affords adduct 16 (entry 12, Table 1) in $76 \%$ yield. The regiochemistry is explained by analysis of the HOMO of furan, in which the 2-position has the highest orbital coefficient. This predicts the furan oxygen will be at the 3position in the cycloadduct.

A wide assortment of benzopyrans are produced with excellent diastereoselectivity via inverse electron demand [4+2] cycloadditions with use of this low-temperature method for generating $o$-QMs from $o$-OBOC salicylaldehydes and alcohols. The $2 \pi$ donors tested include the following in the order of reactivity: imines $>$ enamines $>$ enols $>$ furans $>$ styrenes. Future goals will include the application of this procedure in syntheses of diverse benzopyrans and other natural products, as well as adaptation of the cycloaddition to an asymmetric format. Developments will be reported in due course.

\section{Experimental Section}

\section{General Information}

These reactions required reagents of the highest quality. All reagents were newly purchased or freshly prepared. Starting aryl aldehydes that were not scrupulously dried often led to lower than expected yields. All column chromatography was conducted with silica gel, eluting with the indicated solvent system. The stereochemistry is established via ${ }^{1} \mathrm{H}$ NMR by analysis of ${ }^{1} \mathrm{H}$-couplings and NOE interactions.

5: To a flame-dried 5-mL vial was added alcohol $\mathbf{3}(24.0 \mathrm{mg}, 0.071 \mathrm{mmol})$. Styrene (17, 0.71 $\mathrm{mL})$ was added, and the vial was cooled to $-78{ }^{\circ} \mathrm{C}$. To this mix was added $t-\mathrm{BuMgCl}(\mathbf{2 6}, 53$ $\mu \mathrm{L}, 0.106 \mathrm{mmol}, 2 \mathrm{M}$ in $\mathrm{Et}_{2} \mathrm{O}$ ) dropwise. The reaction was allowed to slowly warm to $\mathrm{rt}$ and was monitored by TLC. Upon completion, the reaction was quenched with $0.1 \mathrm{M} \mathrm{HCl}$ and extracted with $\mathrm{Et}_{2} \mathrm{O}$. After the ether layer was washed with brine, the combined aqueous layers were saturated with $\mathrm{NaCl}$ and extracted with $\mathrm{Et}_{2} \mathrm{O}$. The combined $\mathrm{Et}_{2} \mathrm{O}$ layers were then dried over $\mathrm{Na}_{2} \mathrm{SO}_{4}$, filtered, and concentrated in vacuo. The crude mixture was chromatographed through silica gel eluting with 99:1 petroleum ether/ethyl acetate, yielding $\mathbf{5}$ as a white solid (11.5 mg, 50\% yield). ${ }^{1} \mathrm{H}$ NMR $\left[\mathrm{CDCl}_{3}, 400 \mathrm{MHz}\right] \delta 7.44-7.31(\mathrm{~m}, 5 \mathrm{H}), 7.07(\mathrm{~d}, 1 \mathrm{H}, J=8.24$ $\mathrm{Hz}), 6.75(\mathrm{~d}, 1 \mathrm{H}, J=2.38 \mathrm{~Hz}), 6.70\left(\mathrm{dd}, 1 \mathrm{H}, J_{1}=8.24 \mathrm{~Hz}, J_{2}=2.38 \mathrm{~Hz}\right), 5.06\left(\mathrm{dd}, 1 \mathrm{H}, J_{1}=\right.$ $\left.10.15 \mathrm{~Hz}, J_{2}=2.47 \mathrm{~Hz}\right), 3.01-2.93(\mathrm{~m}, 1 \mathrm{H}), 2.82-2.76(\mathrm{~m}, 1 \mathrm{H}), 2.25-2.19(\mathrm{~m}, 1 \mathrm{H}), 2.13-2.03$ $(\mathrm{m}, 1 \mathrm{H}), 1.56(\mathrm{~s}, 9 \mathrm{H}) ;{ }^{13} \mathrm{C} \mathrm{NMR}\left[\mathrm{CDCl}_{3}, 100 \mathrm{MHz}\right] \delta 155.7,152.2,150.3,141.6,130.0,128.7$, 128.1, 126.2, 119.6, 113.6, 110.2, 94.6, 83.6, 30.0, 27.9, 24.9; IR $\left[\mathrm{CH}_{2} \mathrm{Cl}_{2}, v_{\max } \mathrm{cm}^{-1}\right]$ 3627, 2936, 1756, 1733; MS (EI) $\mathrm{m} / \mathrm{z} 226$ (78), 104 (24), 57 (100); HRMS (EI) $\mathrm{m} / \mathrm{z}$ calcd for $\mathrm{C}_{20} \mathrm{H}_{22} \mathrm{O}_{4} 326.1518$, found 326.1528 .

6: To a flame-dried 5-mL vial was added aldehyde 4 (39.6 mg, $0.12 \mathrm{mmol})$. Styrene (17, 0.59 $\mathrm{mL})$, and $\mathrm{Et}_{2} \mathrm{O}(0.59 \mathrm{~mL})$ were added, and this mixture was cooled to $-20^{\circ} \mathrm{C} . \mathrm{MeLi}(\mathbf{2 7}, 88$ $\mu \mathrm{L}, 0.123 \mathrm{mmol}, 1.4 \mathrm{M}$ in $\mathrm{Et}_{2} \mathrm{O}$ ) was added dropwise, and the resulting solution was stirred for $15 \mathrm{~min}$ at $-20^{\circ} \mathrm{C}$. After $\mathrm{MgBr}_{2} \cdot \mathrm{OEt} 2(37.0 \mathrm{mg}, 0.14 \mathrm{mmol})$ was added to the solution, the reaction was slowly warmed to room temperature. Upon completion, as noted by TLC, the reaction was quenched with $1 \mathrm{M} \mathrm{NaHCO}_{3}$ and extracted with $\mathrm{Et}_{2} \mathrm{O}$. The $\mathrm{Et}_{2} \mathrm{O}$ layer was washed with brine, and the combined aqueous layers were saturated with $\mathrm{NaCl}$. The saturated aqueous layer was washed with $\mathrm{Et}_{2} \mathrm{O}$; the combined $\mathrm{Et}_{2} \mathrm{O}$ extracts were dried over $\mathrm{Na}_{2}-\mathrm{SO}_{4}$, filtered, and concentrated in vacuo. The crude mixture was chromatographed through silica gel eluting with petroleum ether, yielding $\mathbf{6}$ as a white solid $(10.7 \mathrm{mg}$, yield $27 \%) .{ }^{1} \mathrm{H} \mathrm{NMR}\left[\mathrm{CDCl}_{3}, 400\right.$ MHz] $\delta 7.46-7.34$ (m, 5H), 7.28-7.25 (m, 1H), 6.76-6.73 (m, 2H), 5.10-5.07 (m, 1H), 3.20- 
$3.14(\mathrm{~m}, 1 \mathrm{H}), 2.24-2.19(\mathrm{~m}, 1 \mathrm{H}), 1.81(\mathrm{q}, 1 \mathrm{H}, J=11.7 \mathrm{~Hz}), 1.56(\mathrm{~s}, 9 \mathrm{H}), 1.36(\mathrm{~d}, 3 \mathrm{H}, J=6.78$ $\mathrm{Hz}) ;{ }^{13} \mathrm{C}$ NMR $\left[\mathrm{CDCl}_{3}, 100 \mathrm{MHz}\right] \delta 155.5,152.2,150.3,141.6,128.8,128.2,127.8,126.3$, 125.0, 113.7, 110.1, 94.6, 83.7, 40.0, 30.1, 27.9, 20.3; $\mathrm{IR}\left[\mathrm{CH}_{2} \mathrm{Cl}_{2}, v_{\max } \mathrm{cm}^{-1}\right] 3054,2930$, 1757; MS (EI) $m / z 240$ (57), 225 (59), 57 (100); HRMS (EI) $m / z$ calcd for $\mathrm{C}_{21} \mathrm{H}_{24} \mathrm{O}_{4} 340.1675$, found 340.1682 .

7: To a flame-dried 5-mL vial was added aldehyde $4(51.9 \mathrm{mg}, 0.15 \mathrm{mmol})$. Ethyl vinyl ether $(\mathbf{1 8}, 1 \mathrm{~mL})$ was added and the vial was cooled to $-78^{\circ} \mathrm{C}$. To this mixture was added $\mathrm{PhMgBr}$ (28, $192 \mu \mathrm{L}, 0.18 \mathrm{mmol}, 0.96 \mathrm{M}$ in THF) dropwise. The reaction was allowed to slowly warm to $\mathrm{rt}$ and was monitored by TLC. Upon completion, the reaction was quenched with $1 \mathrm{M}$ $\mathrm{NaHCO}_{3}$ and extracted with $\mathrm{Et}_{2} \mathrm{O}$. The ether layer was washed with brine, dried over $\mathrm{Na}_{2} \mathrm{SO}_{4}$, filtered, and concentrated in vacuo. The crude mixture was then chromatographed through silica gel, eluting with 98:2 petroleum ether/ethyl acetate, yielding 7 as a white solid (41.3 mg, yield 73\%). ${ }^{1} \mathrm{H}$ NMR [ $\left.\mathrm{CDCl}_{3}, 400 \mathrm{MHz}\right] \delta 7.35-7.30(\mathrm{~m}, 2 \mathrm{H}), 7.28-7.24(\mathrm{~m}, 1 \mathrm{H})$, $7.21-7.19(\mathrm{~m}, 2 \mathrm{H}), 6.75(\mathrm{~d}, 1 \mathrm{H}, J=2.38 \mathrm{~Hz}), 6.69\left(\mathrm{dd}, 1 \mathrm{H}, J_{1}=8.42 \mathrm{~Hz}, J_{2}=0.92 \mathrm{~Hz}\right), 6.60$ $\left(\mathrm{dd}, 1 \mathrm{H}, J_{1}=8.42 \mathrm{~Hz}, J_{2}=2.38 \mathrm{~Hz}\right), 5.27\left(\mathrm{dd}, 1 \mathrm{H}, J_{1}=8.61 \mathrm{~Hz}, J_{2}=2.38 \mathrm{~Hz}\right), 4.18-4.14(\mathrm{~m}$, $1 \mathrm{H}), 4.11-4.03(\mathrm{~m}, 1 \mathrm{H}), 3.71-3.63(\mathrm{~m}, 1 \mathrm{H}), 2.41-2.36(\mathrm{~m}, 1 \mathrm{H}), 2.23-2.15(\mathrm{~m}, 1 \mathrm{H}), 1.56(\mathrm{~s}$, 9H), $1.27(\mathrm{t}, 3 \mathrm{H}, J=7.05 \mathrm{~Hz}) ;{ }^{13} \mathrm{C} \mathrm{NMR}\left[\mathrm{CDCl}_{3}, 100 \mathrm{MHz}\right] \delta 154.2,152.1,150.6,144.0$, 130.1, 128.8, 127.0, 123.6, 114.0, 110.2, 99.9, 94.6, 83.7, 64.7, 41.2, 37.3, 27.9, 15.4; IR $\left[\mathrm{CH}_{2} \mathrm{Cl}_{2}, v_{\max } \mathrm{cm}^{-1}\right]$ 2982, 1757; MS (EI) $\mathrm{m} / \mathrm{z} 311$ (34), 224 (56), 57 (100); HRMS (EI) $\mathrm{m} / \mathrm{z}$ calcd for $\mathrm{C}_{22} \mathrm{H}_{26} \mathrm{O}_{5} 370.1780$, found 370.1783 .

8: To a flame-dried 5-mL vial was added aldehyde $4(78.8 \mathrm{mg}, 0.23 \mathrm{mmol})$. Ethyl vinyl ether $(\mathbf{1 8}, 2.3 \mathrm{~mL})$ was added and the vial was cooled to $-78^{\circ} \mathrm{C}$. To this mixture was added vinylmagnesium bromide (29, $270 \mu \mathrm{L}, 0.25 \mathrm{mmol}, 0.955 \mathrm{M}$ in THF) dropwise. The reaction was slowly warmed to room tempearture and monitored by TLC. Upon completion, the reaction was quenched with $1 \mathrm{M} \mathrm{NaHCO}_{3}$, and extracted with $\mathrm{Et}_{2} \mathrm{O}$. The $\mathrm{Et}_{2} \mathrm{O}$ layer was washed with brine; the combined aqueous layers were saturated with $\mathrm{NaCl}$ and extracted with $\mathrm{Et}_{2} \mathrm{O}$. The combined $\mathrm{Et}_{2} \mathrm{O}$ layers were dried over $\mathrm{Na}_{2} \mathrm{SO}_{4}$, filtered, and concentrated in vacuo. The crude mixture was chromatographed through silica gel, eluting with 98:2 petroleum ether/ethyl acetate, yielding 8 as a white solid $(52.0 \mathrm{mg}$, yield $70 \%) .{ }^{1} \mathrm{H} \mathrm{NMR}\left[\mathrm{CDCl}_{3}, 400 \mathrm{MHz}\right] \delta 7.09$ $\left(\mathrm{dt}, 1 \mathrm{H}, J_{1}=8.06 \mathrm{~Hz}, J_{2}=0.92 \mathrm{~Hz}\right), 6.72-6.69(\mathrm{~m}, 2 \mathrm{H}), 5.95-5.86(\mathrm{~m}, 1 \mathrm{H}), 5.22-5.09(\mathrm{~m}$, $3 \mathrm{H}), 4.03-3.95(\mathrm{~m}, 1 \mathrm{H}), 3.67-3.59(\mathrm{~m}, 1 \mathrm{H}), 3.53-3.47(\mathrm{~m}, 1 \mathrm{H}), 2.23-2.17(\mathrm{~m}, 1 \mathrm{H}), 1.97-1.89$ $(\mathrm{m}, 1 \mathrm{H}), 1.56(\mathrm{~s}, 9 \mathrm{H}), 1.25(\mathrm{t}, 3 \mathrm{H}, J=7.05 \mathrm{~Hz}) ;{ }^{13} \mathrm{C} \mathrm{NMR}\left[\mathrm{CDCl}_{3}, 100 \mathrm{MHz}\right] \delta 153.1,152.1$, 150.7, 141.3, 129.8, 121.8, 115.9, 113.9, 110.3, 98.8, 83.7, 64.6, 39.2, 34.2, 27.9, 15.4; IR $\left[\mathrm{CH}_{2} \mathrm{Cl}_{2}, v_{\max } \mathrm{cm}^{-1}\right]$ 2980, 1757, 1614; MS FAB m/z 261 (24), 174 (54), 57 (100); HRMS (EI) $m / z$ calcd for $\mathrm{C}_{18} \mathrm{H}_{24} \mathrm{O}_{5} 320.1624$, found 320.1616 .

9: To a flame-dried 5-mL vial was added aldehyde $4(30.1 \mathrm{mg}, 0.089 \mathrm{mmol})$. Ethyl vinyl ether $(18,0.89 \mathrm{~mL})$ was added and the vial was cooled to $-78^{\circ} \mathrm{C}$. To this solution was added dimethylphenylsilyllithium (30,740 $\mu \mathrm{L}, 0.27 \mathrm{mmol}, 0.36 \mathrm{M}$ in THF) dropwise. The reaction was stirred at $-78^{\circ} \mathrm{C}$ for $30 \mathrm{~min}$. After $\mathrm{MgBr}_{2} \cdot \mathrm{OEt}_{2}(32.2 \mathrm{mg}, 0.125 \mathrm{mmol})$ was added to the solution, the reaction was slowly warmed to room temperature. Upon completion, as noted by TLC, the reaction was quenched with $1 \mathrm{M} \mathrm{NaHCO}_{3}$ and extracted with $\mathrm{Et}_{2} \mathrm{O}$. The $\mathrm{Et}_{2} \mathrm{O}$ layer was washed with brine, and the combined aqueous layers were saturated with $\mathrm{NaCl}$. After the saturated aqueous layer was washed with $\mathrm{Et}_{2} \mathrm{O}$, the combined $\mathrm{Et}_{2} \mathrm{O}$ extracts were dried over $\mathrm{Na}_{2} \mathrm{SO}_{4}$, filtered, and concentrated in vacuo. The crude mixture was chromatographed through silica gel eluting with 98:2 petroleum ether/ethyl acetate, yielding $\mathbf{9}$ as a white solid (32.8 $\mathrm{mg}$, yield $86 \%) .{ }^{1} \mathrm{H}$ NMR $\left[\mathrm{CDCl}_{3}, 400 \mathrm{MHz}\right] \delta 7.54-7.52(\mathrm{~m}, 2 \mathrm{H}), 7.38-7.36(\mathrm{~m}, 3 \mathrm{H}), 6.75(\mathrm{dd}$, $\left.1 \mathrm{H}, J_{1}=8.42 \mathrm{~Hz}, J_{2}=0.73 \mathrm{~Hz}\right), 6.66(\mathrm{~d}, 1 \mathrm{H}, J=2.38 \mathrm{~Hz}), 6.57\left(\mathrm{dd}, 1 \mathrm{H}, J_{1}=8.42 \mathrm{~Hz}, J_{2}=\right.$ $2.56 \mathrm{~Hz}), 5.09-5.07(\mathrm{~m}, 1 \mathrm{H}), 4.00-3.92(\mathrm{~m}, 1 \mathrm{H}), 3.66-3.58(\mathrm{~m}, 1 \mathrm{H}), 2.64-2.61(\mathrm{~m}, 1 \mathrm{H}), 2.15-$ $2.09(\mathrm{~m}, 1 \mathrm{H}), 2.06-2.00(\mathrm{~m}, 1 \mathrm{H}), 1.55(\mathrm{~s}, 9 \mathrm{H}), 1.25(\mathrm{t}, 3 \mathrm{H}, J=7.05 \mathrm{~Hz}), 0.32(\mathrm{~s}, 3 \mathrm{H}), 0.26(\mathrm{~s}$, $3 \mathrm{H}) ;{ }^{13} \mathrm{C}$ NMR $\left[\mathrm{CDCl}_{3}, 100 \mathrm{MHz}\right] \delta 152.7,152.1,149.2,139.5,134.3,129.1,128.5,128.0$, 
122.6, 113.6, 110.4, 98.3, 83.5, 64.4, 29.2, 27.9, 22.3, 15.3, -2.8, -3.9; IR $\left[\mathrm{CH}_{2} \mathrm{Cl}_{2}, v_{\max }\right.$ $\mathrm{cm}^{-1}$ ] 2983, 1757, 1613; MS (EI) $\mathrm{m} / z$ 148 (67), 135 (77), 57 (100); HRMS (EI) $\mathrm{m} / \mathrm{z}$ calcd for $\mathrm{C}_{24} \mathrm{H}_{32} \mathrm{O}_{5} \mathrm{Si} 428.2019$, found 428.2018.

10: To a flame-dried 5-mL vial was added aldehyde 4 (32.0 mg, $0.095 \mathrm{mmol})$. Dihydropyran $(\mathbf{1 9}, 0.95 \mathrm{~mL})$ was added and the vial was cooled to $-78^{\circ} \mathrm{C}$. To this mixture was added $\mathrm{MeMgCl}$ $(31,37 \mu \mathrm{L}, 0.104 \mathrm{mmol}, 2.85 \mathrm{M}$ in THF) dropwise. The reaction was slowly warmed to $\mathrm{rt}$ and monitored by TLC. Upon completion, the reaction was quenched with $1 \mathrm{M} \mathrm{NaHCO}_{3}$ and extracted with $\mathrm{Et}_{2} \mathrm{O}$. The $\mathrm{Et}_{2} \mathrm{O}$ layer was washed with brine; the combined aqueous layers were saturated with $\mathrm{NaCl}$ and extracted with $\mathrm{Et}_{2} \mathrm{O}$. The combined $\mathrm{Et}_{2} \mathrm{O}$ layers were dried over $\mathrm{Na}_{2} \mathrm{SO}_{4}$, filtered, and concentrated in vacuo. The crude mixture was chromatographed through silica gel, eluting with 98:2 petroleum ether/ethyl acetate, yielding $\mathbf{1 0}$ as a white solid (20 mg, yield $66 \%) .{ }^{1} \mathrm{H} \mathrm{NMR}\left[\mathrm{CDCl}_{3}, 400 \mathrm{MHz}\right] \delta 7.11\left(\mathrm{dt}, 1 \mathrm{H}, J_{1}=7.69 \mathrm{~Hz}, J_{2}=1.28 \mathrm{~Hz}\right), 6.73-$ $6.70(\mathrm{~m}, 2 \mathrm{H}), 5.48(\mathrm{~d}, 1 \mathrm{H}, J=2.56 \mathrm{~Hz}), 4.00-3.94(\mathrm{~m}, 1 \mathrm{H}), 3.77-3.73(\mathrm{~m}, 1 \mathrm{H}), 3.14$ (quintet, $1 \mathrm{H}, J=6.41 \mathrm{~Hz}), 2.04-2.00(\mathrm{~m}, 1 \mathrm{H}), 1.77-1.65(\mathrm{~m}, 1 \mathrm{H}), 1.64-1.58(\mathrm{~m}, 3 \mathrm{H}), 1.56(\mathrm{~s}, 9 \mathrm{H}), 1.30$ $(\mathrm{d}, 3 \mathrm{H}, J=7.14 \mathrm{~Hz}) ;{ }^{13} \mathrm{C} \mathrm{NMR}\left[\mathrm{CDCl}_{3}, 100 \mathrm{MHz}\right] \delta 154.3,152.2,150.6,127.2,122.3,113.8$, 109.2, 97.5, 83.7, 61.1, 38.0, 32.0, 27.9, 24.7, 17.6, 15.4; IR $\left[\mathrm{CH}_{2} \mathrm{Cl}_{2}, v_{\max } \mathrm{cm}^{-1}\right] 2978,1758$, 1613; MS (EI) $m / z 220$ (53), 205 (75), 57 (100); HRMS (EI) $m / z$ calcd for $\mathrm{C}_{18} \mathrm{H}_{24} \mathrm{O}_{5} 320.1624$, found 320.1617 .

11: To a flame-dried 5-mL vial was added aldehyde 4 (29.2 mg, $0.086 \mathrm{mmol})$. Enol ether 20 $(116 \mathrm{mg}, 0.86 \mathrm{mmol})$ and toluene $(0.86 \mathrm{~mL})$ were added and the vial was cooled to $0{ }^{\circ} \mathrm{C}$. To this mixture was added $\mathrm{MeMgCl}(\mathbf{3 1}, 46 \mu \mathrm{L}, 0.14 \mathrm{mmol}, 3 \mathrm{M}$ in THF $)$ dropwise. The reaction was slowly warmed to $\mathrm{rt}$ and monitored by TLC. Upon completion, the reaction was quenched with $1 \mathrm{M} \mathrm{NaHCO}_{3}$ and extracted with $\mathrm{Et}_{2} \mathrm{O}$. The $\mathrm{Et}_{2} \mathrm{O}$ layer was washed with brine, then dried over $\mathrm{Na}_{2} \mathrm{SO}_{4}$, filtered, and concentrated in vacuo. The crude mixture was chromatographed through silica gel, eluting with 99:1 petroleum ether/ethyl acetate, yielding $\mathbf{1 1}$ as white solid (17.5 mg, yield 55\%, inseparable mix of diastereomers). Major isomer: ${ }^{1} \mathrm{H}$ NMR $\left[\mathrm{CDCl}_{3}, 400\right.$ $\mathrm{MHz}] \delta 7.61-7.28(\mathrm{~m}, 5 \mathrm{H}), 7.17\left(\mathrm{dd}, 1 \mathrm{H}, J_{1}=8.42 \mathrm{~Hz}, J_{2}=0.92 \mathrm{~Hz}\right), 6.89(\mathrm{~d}, 1 \mathrm{H}, J=2.38$ $\mathrm{Hz}$ ), $6.79\left(\mathrm{dd}, 1 \mathrm{H}, J_{1}=8.42 \mathrm{~Hz}, J_{2}=2.38 \mathrm{~Hz}\right), 3.13(\mathrm{~s}, 3 \mathrm{H}), 2.73$ (sextet, $1 \mathrm{H}, J=6.78 \mathrm{~Hz}$ ), $2.15\left(\mathrm{qd}, 2 \mathrm{H}, J_{1}=42.3 \mathrm{~Hz}, J_{2}=13.73 \mathrm{~Hz}, J_{3}=6.23 \mathrm{~Hz}\right), 1.58(\mathrm{~s}, 9 \mathrm{H}), 1.43(\mathrm{~d}, 3 \mathrm{H}, J=7.14$ $\mathrm{Hz}) ;{ }^{13} \mathrm{C} \mathrm{NMR}\left[\mathrm{CDCl}_{3}, 100 \mathrm{MHz}\right] \delta 153.0,152.2,150.3,141.2,128.6,127.5,126.5,125.6$, 114.2, 110.2, 102.3, 101.0, 83.6, 50.3, 41.8, 27.9, 27.5, 22.2; IR $\left[\mathrm{CH}_{2} \mathrm{Cl}_{2}, v_{\max } \mathrm{cm}^{-1}\right] 2967$, 2935, 1758; MS (EI) m/z 255 (29), 223 (24), 57 (100); HRMS (EI) $m / z$ calcd for $\mathrm{C}_{22} \mathrm{H}_{26} \mathrm{O}_{5}$ 370.1780 , found 370.1790 .

\section{General Procedure for Compounds 12 and 13}

A flame-dried flask containing aldehyde $4\left(0.1 \mathrm{M}\right.$ in $\left.\mathrm{Et}_{2} \mathrm{O}\right)$ was cooled to $-78{ }^{\circ} \mathrm{C}$. The appropriate organolithium reagent was added in dropwise fashion. After the mixture was stirred for $15 \mathrm{~min}$, the dienophile ( 5 equiv) was added, followed 5 min later by $\mathrm{MgBr}_{2} \cdot \mathrm{OEt}_{2}$ ( 1 equiv), and the reaction was permitted to slowly warm to rt. Upon completion by TLC, $400 \mathrm{mg}$ of

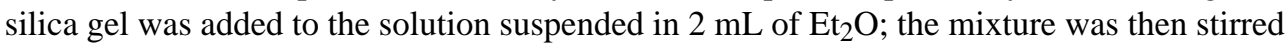
for $3 \mathrm{~h}$. The reaction was then quenched with $1 \mathrm{M} \mathrm{NaHCO}_{3}$ and extracted with an equal volume of $\mathrm{Et}_{2} \mathrm{O}$. The ether layer was washed with an equal volume of brine, and the organic layer was then dried over $\mathrm{Na}_{2} \mathrm{SO}_{4}$, filtered, and concentrated in vacuo.

12: White solid (NMR yield 52\%). ${ }^{1} \mathrm{H}$ NMR $\left[\mathrm{CDCl}_{3}, 400 \mathrm{MHz}\right] \delta 7.61(\mathrm{~s}, 1 \mathrm{H}), 7.18(\mathrm{~d}, 1 \mathrm{H}$, $J=8.29 \mathrm{~Hz}), 6.94\left(\mathrm{dd}, 1 \mathrm{H}, J_{1}=8.29 \mathrm{~Hz}, J_{2}=2.3 \mathrm{~Hz}\right), 6.87(\mathrm{~d}, 1 \mathrm{H}, J=2.3 \mathrm{~Hz}), 3.93(\mathrm{q}, 1 \mathrm{H}$, $J=6.76 \mathrm{~Hz}), 2.32(\mathrm{~s}, 3 \mathrm{H}), 1.57(\mathrm{~s}, 9 \mathrm{H}), 1.27(\mathrm{~d}, 3 \mathrm{H}, J=6.91 \mathrm{~Hz}) ;{ }^{13} \mathrm{C} \mathrm{NMR}\left[\mathrm{CDCl}_{3}, 100\right.$ $\mathrm{MHz}] \delta 195.9,152.0,150.1,129.7,124.3,122.0,118.2,109.9,84.1,77.4,29.9,27.9,27.3$, 25.6, 25.5; IR $\left[\mathrm{CH}_{2} \mathrm{Cl}_{2}, v_{\max } \mathrm{cm}^{-1}\right] 2928,1759,1644,1587,1501 ; \mathrm{MS}$ (EI) $\mathrm{m} / \mathrm{z} 204$ (21), 189 (90), 57 (100); HRMS (EI) $\mathrm{m} / z$ calcd for $\mathrm{C}_{17} \mathrm{H}_{20} \mathrm{O}_{5} 304.1311$, found 304.1315. 
13: Brown oil (NMR yield 56\%). ${ }^{1} \mathrm{H}$ NMR $\left[\mathrm{CDCl}_{3}, 400 \mathrm{MHz}\right] \delta 7.95(\mathrm{~d}, 2 \mathrm{H}, J=7.37 \mathrm{~Hz})$, $7.58(\mathrm{t}, 1 \mathrm{H}, J=7.37 \mathrm{~Hz}), 7.45(\mathrm{t}, 2 \mathrm{H}, J=7.7 \mathrm{~Hz}), 7.18(\mathrm{~d}, 1 \mathrm{H}, J=8.29 \mathrm{~Hz}), 6.76-6.72(\mathrm{~m}$, $2 \mathrm{H}), 3.78-3.73(\mathrm{~m}, 1 \mathrm{H}), 3.47\left(\mathrm{dd}, 1 \mathrm{H}, J_{1}=18.77 \mathrm{~Hz}, J_{2}=9.52 \mathrm{~Hz}\right), 3.29\left(\mathrm{dd}, 1 \mathrm{H}, J_{1}=18.58\right.$

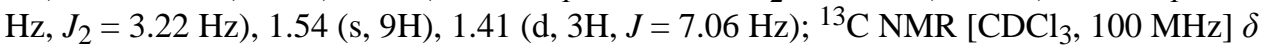
201.8, 154.8, 152.2, 150.3, 136.2, 134.0, 130.8, 128.9, 128.6, 127.1, 114.1, 111.2, 83.6, 48.7, 27.9, 26.2, 21.7; IR $\left[\mathrm{CH}_{2} \mathrm{Cl}_{2}, v_{\max } \mathrm{cm}^{-1}\right]$ 3686, 3053, 2960, 2928, 2855, 1755, 1733, 1671, 1599; MS (EI) $m / z 281$ (60), 57 (74), 43 (100); HRMS (EI) $m / z(\mathrm{M}+\mathrm{Na})^{+}$calcd for $\mathrm{C}_{21} \mathrm{H}_{24} \mathrm{O}_{5} \mathrm{Na}+379.1521$, found 379.1527 .

14: To a flame-dried 5-mL vial was added aldehyde 4 (32.5 mg, $0.096 \mathrm{mmol})$. Diethyl ether $(0.96 \mathrm{~mL})$ and enamine $23(161 \mu \mathrm{L}, 0.96 \mathrm{mmol})$ were added and the vial was cooled to $-78^{\circ}$ C. To this mixture was added vinylmagnesium chloride $(\mathbf{2 9}, 110 \mu \mathrm{L}, 0.106 \mathrm{mmol}, 0.955 \mathrm{M}$ in THF) dropwise. The reaction was slowly warmed to $\mathrm{rt}$ and monitored by TLC. Upon completion, the reaction was quenched with $1 \mathrm{M} \mathrm{NaHCO}_{3}$ and extracted with $\mathrm{Et}_{2} \mathrm{O}$. The $\mathrm{Et}_{2} \mathrm{O}$ layer was washed with brine; the combined aqueous layers were saturated with $\mathrm{NaCl}$ and extracted with $\mathrm{Et}_{2} \mathrm{O}$. The combined $\mathrm{Et}_{2} \mathrm{O}$ layers were dried over $\mathrm{Na}_{2} \mathrm{SO}_{4}$, filtered, and concentrated in vacuo. The crude mixture was chromatographed through silica gel, eluting with 98:2 petroleum ether/ethyl acetate, yielding 14 as a white solid (28.0 mg, yield $70 \%) .{ }^{1} \mathrm{H} \mathrm{NMR}$ $\left.\left[\mathrm{CDCl}_{3}, 400 \mathrm{MHz}\right] \delta 7.06\left(\mathrm{dt}, 1 \mathrm{H}, J_{1}=8.06 \mathrm{~Hz}, J_{2}\right) 0.916 \mathrm{~Hz}\right), 6.67-6.64(\mathrm{~m}, 2 \mathrm{H}), 5.87-5.78$ $(\mathrm{m}, 1 \mathrm{H}), 5.22-5.14(\mathrm{~m}, 2 \mathrm{H}), 3.70-3.60(\mathrm{~m}, 4 \mathrm{H}), 3.36-3.32(\mathrm{~m}, 1 \mathrm{H}), 2.82-2.71(\mathrm{~m}, 4 \mathrm{H}), 2.15-$ $2.10(\mathrm{~m}, 1 \mathrm{H}), 1.84-1.72(\mathrm{~m}, 3 \mathrm{H}), 1.66-1.56(\mathrm{~m}, 12 \mathrm{H}), 1.49(\mathrm{~s}, 1 \mathrm{H}), 1.42-1.36(\mathrm{~m}, 1 \mathrm{H}) ;{ }^{13} \mathrm{C}$ NMR $\left[\mathrm{CDCl}_{3}, 100 \mathrm{MHz}\right] \delta 153.4,152.2,150.9,142.1,130.3,120.8,116.3,113.1,109.8,91.6$, 83.4, 67.6, 45.0, 44.0, 38.0, 29.9, 28.0, 27.8, 22.6, 22.1; IR [ $\mathrm{CH}_{2} \mathrm{Cl}_{2}$ solution, $\left.v_{\max } \mathrm{cm}^{-1}\right] 2936$, 2858, 1757, 1610, 1591, 1498; MS (EI) m/z 167 (100), 57 (14), 43 (15); HRMS (EI) m/z calcd for $\mathrm{C}_{24} \mathrm{H}_{33} \mathrm{NO}_{5} 415.2359$, found 415.2348.

15: To a flame-dried 5-mL vial was added aldehyde 4 (33.3 mg, $0.098 \mathrm{mmol})$. Ether (1 mL) and imine $24(100 \mu \mathrm{L}, 0.49 \mathrm{mmol})$ were added and the vial was cooled to $-78^{\circ} \mathrm{C}$. To this mixture was added $\mathrm{MeMgCl}(\mathbf{3 1}, 41 \mu \mathrm{L}, 0.108 \mathrm{mmol}, 2.65 \mathrm{M}$ in THF $)$ dropwise. The reaction was slowly warmed to rt and monitored by TLC. Upon completion, the reaction was quenched with $1 \mathrm{M} \mathrm{NaHCO}_{3}$ and extracted with $\mathrm{Et}_{2} \mathrm{O}$. The $\mathrm{Et}_{2} \mathrm{O}$ layer was washed with brine; the combined aqueous layers were saturated with $\mathrm{NaCl}$ and extracted with $\mathrm{Et}_{2} \mathrm{O}$. The combined $\mathrm{Et}_{2} \mathrm{O}$ layers were dried over $\mathrm{Na}_{2} \mathrm{SO}_{4}$, filtered, and concentrated in vacuo. The crude mixture was chromatographed through silica gel, eluting with petroleum ether, yielding $\mathbf{1 5}$ as a white solid (40.0 mg, yield 94\%). ${ }^{1} \mathrm{H}$ NMR $\left[\mathrm{CDCl}_{3}, 400 \mathrm{MHz}\right] \delta 7.77-7.75(\mathrm{~m}, 2 \mathrm{H}), 7.45-7.41(\mathrm{~m}$, 2H), 7.35-7.29 (m, 5H), 7.25-7.22 (m, 1H), 6.99 (d, 1H, J = 8.42 Hz), 6.89 (d, 1H, J = 2.38 $\mathrm{Hz}), 6.75\left(\mathrm{dd}, 1 \mathrm{H}, J_{1}=8.42 \mathrm{~Hz}, J_{2}=2.38 \mathrm{~Hz}\right), 6.09(\mathrm{~s}, 1 \mathrm{H}), 3.86-3.79(\mathrm{~m}, 2 \mathrm{H}), 3.34(\mathrm{~d}, 1 \mathrm{H}$, $J=14.83 \mathrm{~Hz}), 1.59(\mathrm{~s}, 9 \mathrm{H}), 1.55(\mathrm{~d}, 1 \mathrm{H}, J=6.96 \mathrm{~Hz}) ;{ }^{13} \mathrm{C} \mathrm{NMR}\left[\mathrm{CDCl}_{3}, 100 \mathrm{MHz}\right] \delta 154.8$, 152.3, 150.3, 139.6, 138.2, 129.3, 128.5, 128.4, 128.2, 128.1, 127.0, 126.7, 123.0, 114.1, 110.2, 86.0, 83.8, 52.4, 49.8, 27.9, 24.1; IR $\left[\mathrm{CH}_{2} \mathrm{Cl}_{2}, v_{\max } \mathrm{cm}^{-1}\right]$ 2975, 2935, 1758, 1617; MS FAB $m / z 136$ (27), 91 (100) 57 (82); HRMS (EI) m/z calcd for $\mathrm{C}_{27} \mathrm{H}_{29}-\mathrm{NO}_{4} 431.2097$, found 430.2113 .

16: To a flame-dried 5-mL vial was added aldehyde 4 (36.2 mg, $0.107 \mathrm{mmol})$. Furan (25, 1.07 $\mathrm{mL})$ was added and the vial was cooled to $-78^{\circ} \mathrm{C}$. To this mixture was added $\mathrm{MeMgCl}(\mathbf{3 1}$, $48 \mu \mathrm{L}, 0.118 \mathrm{mmol}, 2.45 \mathrm{M}$ in THF) dropwise. The reaction was slowly warmed to $\mathrm{rt}$ and monitored by TLC. Upon completion, the reaction was quenched with $1 \mathrm{M} \mathrm{NaHCO}_{3}$ and extracted with $\mathrm{Et}_{2} \mathrm{O}$. The $\mathrm{Et}_{2} \mathrm{O}$ layer was washed with brine; the combined aqueous layers were saturated with $\mathrm{NaCl}$ and extracted with $\mathrm{Et}_{2} \mathrm{O}$. The combined $\mathrm{Et}_{2} \mathrm{O}$ layers were dried over $\mathrm{Na}_{2} \mathrm{SO}_{4}$, filtered, and concentrated in vacuo. The crude mixture was chromatographed through silica gel, eluting with 98:2 petroleum ether/ethyl acetate, yielding $\mathbf{1 6}$ as a white solid $(24.7$ mg, yield 76\%). ${ }^{1} \mathrm{H}$ NMR $\left[\mathrm{CDCl}_{3}, 400 \mathrm{MHz}\right] \delta 7.15\left(\mathrm{dd}, 1 \mathrm{H}, J_{1}=8.24 \mathrm{~Hz}, J_{2}=1.28 \mathrm{~Hz}\right), 6.83$ $\left(\mathrm{dd}, 1 \mathrm{H}, J_{1}=8.24 \mathrm{~Hz} J_{2}=2.38 \mathrm{~Hz}\right), 6.71(\mathrm{~d}, 1 \mathrm{H}, J=2.38 \mathrm{~Hz}), 6.39-6.37(\mathrm{~m}, 1 \mathrm{H}), 5.5(\mathrm{ddd}$, 
$\left.1 \mathrm{H}, J_{1}=8.24 \mathrm{~Hz}, J_{2}=2.56 \mathrm{~Hz}, J_{3}=0.92 \mathrm{~Hz}\right), 5.07\left(\mathrm{td}, 1 \mathrm{H}, J_{1}=2.56 \mathrm{~Hz}, J_{2}=0.37 \mathrm{~Hz}\right), 4.92$ $\left(\mathrm{dd}, 1 \mathrm{H}, J_{1}=8.24 \mathrm{~Hz}, J_{2}=2.93 \mathrm{~Hz}\right), 3.08\left(\mathrm{qd}, 1 \mathrm{H}, J_{1}=6.96 \mathrm{~Hz}, J_{2}=2.93 \mathrm{~Hz}\right), 1.58-1.53(\mathrm{~m}$, $12 \mathrm{H}) ;{ }^{13} \mathrm{C}$ NMR $\left[\mathrm{CDCl}_{3}, 100 \mathrm{MHz}\right] \delta 155.2,152.0,151.8,150.4,126.6,126.2,115.1,111.9$, 101.5, 85.2, 83.6, 82.3, 31.1, 27.9, 13.7; IR [ $\left.\mathrm{CH}_{2} \mathrm{Cl}_{2}, v_{\max } \mathrm{cm}^{-1}\right]$ 2975, 2935, 1758, 1612; MS (EI) $\mathrm{m} / z 189$ (46), 136 (27), 57 (100); HRMS (EI) $\mathrm{m} / z$ calcd for $\mathrm{C}_{17} \mathrm{H}_{20} \mathrm{O}_{5} 304.1311$, found 304.1316.

\section{Acknowledgements}

Research support from the University of California Coordinating Committee on Cancer Research in the form of two awards (19990641 and SB010064) is greatly appreciated along with additional support from NSF (CHE-9971211), PRF (PRF34986-G1), NIH (GM-64831), the UC-AIDS Initiative (K00-SB-039), and Research Corporation (R10296). We are also thankful for the support of our M.S. facility funded in part by DAAD19-00-1-0026.

\section{References}

1. Nicolaou KC, Pfefferkorn JA, Barluenga S, Mitchell HJ, Roecker AJ, Cao GQ. J Am Chem Soc 2000;122:9968-9976.Nicolaou KC, Pfefferkorn JA, Roecker AJ, Cao GQ, Barluenga S, Mitchell HJ. J Am Chem Soc 2000;122:9939-9953.Nicolaou KC, Pfefferkorn JA, Mitchell HJ, Roecker AJ, Barluenga S, Cao GQ, Affleck RL, Lillig JE. J Am Chem Soc 2000;122:9954-9967.

2. Ogundaini A, Farah M, Perera P. J Nat Prod 1996;59:587-590. [PubMed: 8786365]

3. Chino M, Nishikawa K, Yamada A, Ohsono M, Sawa T, Hanaoka F, Ishizuka M, Takeuchi T. J Antibiot 1998;51:480-486. [PubMed: 9666176]

4. (a) Van De Water RW, Magdziak DJ, Chau JN, Pettus TRR. J Am Chem Soc 2000;122:6502-6503. (b) Jones RM, Van De Water RW, Lindsey CC, Hoarau C, Ung T, Pettus TRR. J Org Chem 2001;66:3435-3441. [PubMed: 11348127] (c) Hoarau C, Pettus TRR. Molecules. 2002in press

5. Turner AB. Q Rev 1964;18:347-360.

6. Talley JJ. J Org Chem 1985;50:1695-1699.

7. Chambers JD, Crawford J, Williams HWR, Dufresne C, Scheigetz J, Bernstein MA, Lau CK. Can J Chem 1992;70:1717-1732.Inoue T, Inoue S, Sato K. Bull Chem Soc Jpn 1990;63:1062-1068.

8. McLoughlin BJ. J Chem Soc, Chem Commun 1969:540-541.

9. Lipshutz BH, Sclafani JA, Takanami T. J Am Chem Soc 1998;120:4021-4022.

10. Gassman PG, Burns SJ, Pfister KB. J Org Chem 1993;58:1449-1457.

11. Kozmin SA, Janey JM, Rawal VH. J Org Chem 1999;64:3039-3052. [PubMed: 11674400]Kanner CB, Pandit UK. Tetrahedron 1982;38:3597-3604.

12. Pine S, Pettit RJ, Gieb GD, Cruz SG, Gallego CH, Tijerina T, Pine RD. J Org Chem 1985;50:12121216.Petasis N, Lu SP. Tetrahedron Lett 1995;36:2393-2396. 

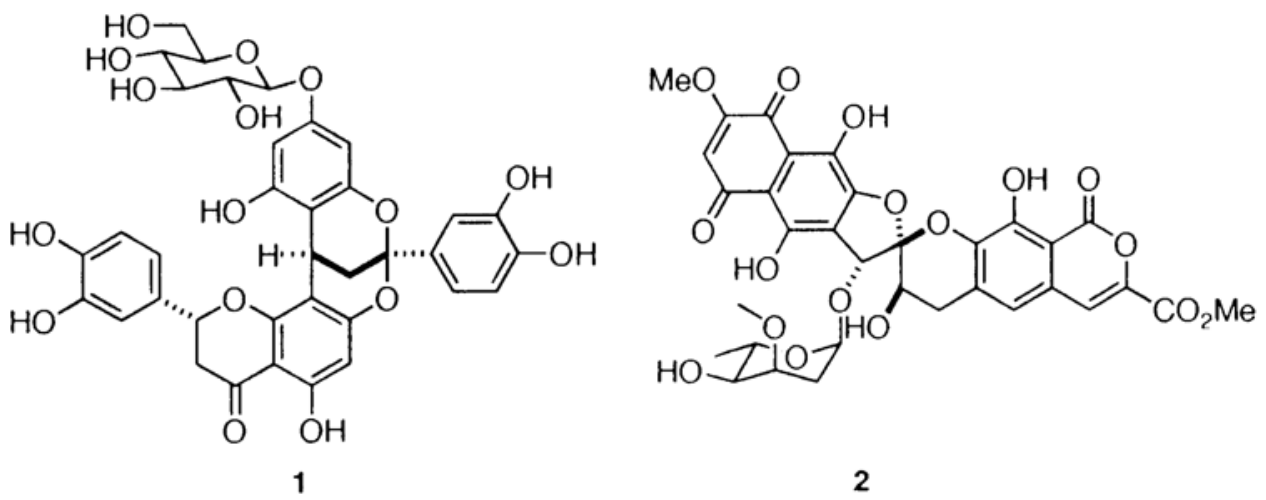

FIGURE 1.

Examples of biologically active benzopyrans. 

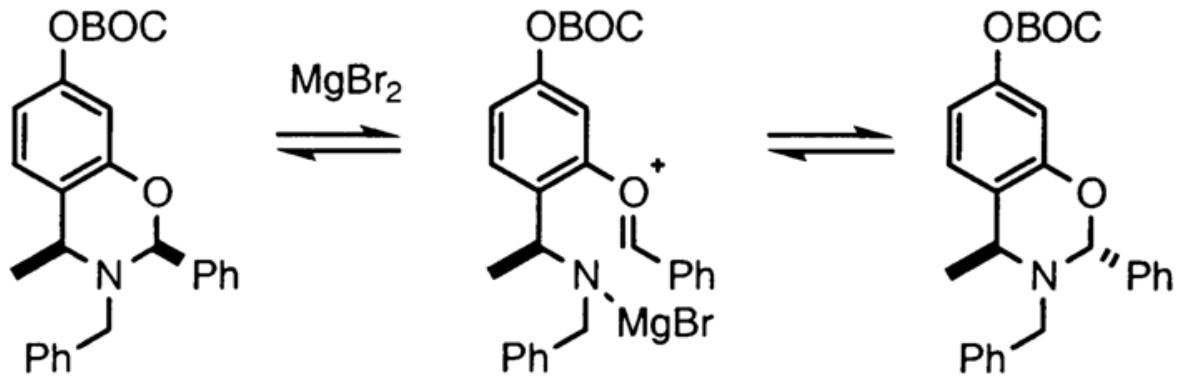

FIGURE 2.

Equilibration of the stereochemistry in $\mathbf{1 5}$. 

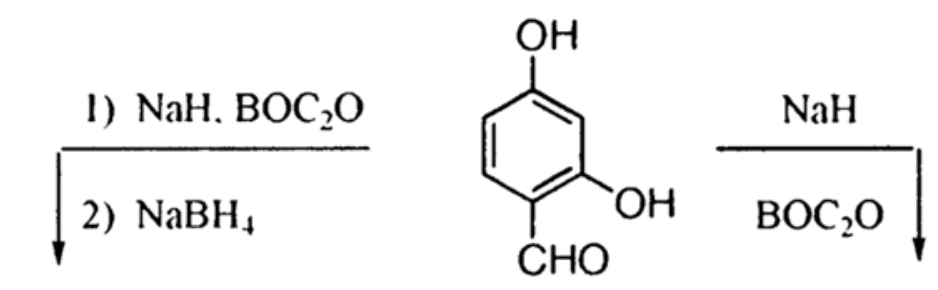<smiles>CC(=O)Oc1ccc(CO)c(O[R6](=O)[O-])c1</smiles><smiles>[3H]CC</smiles><smiles>[R][W]</smiles><smiles>[3H]CC</smiles><smiles>CC(=O)Oc1ccc(C=O)c(O[R6](=O)[O-])c1</smiles><smiles>[R9]C=C1C=CC(O[R6](=O)OCc2ccc(OC(C)=O)cc2)=CC1=O</smiles><smiles>[R6]Oc1ccc2c(c1)OC([Y])([Y])C([Z])C2</smiles><smiles>[Z]C=C([X])CCCC</smiles>

Scheme 1.

Cycloadditions of Salicylic Aldehydes and Alcohols 


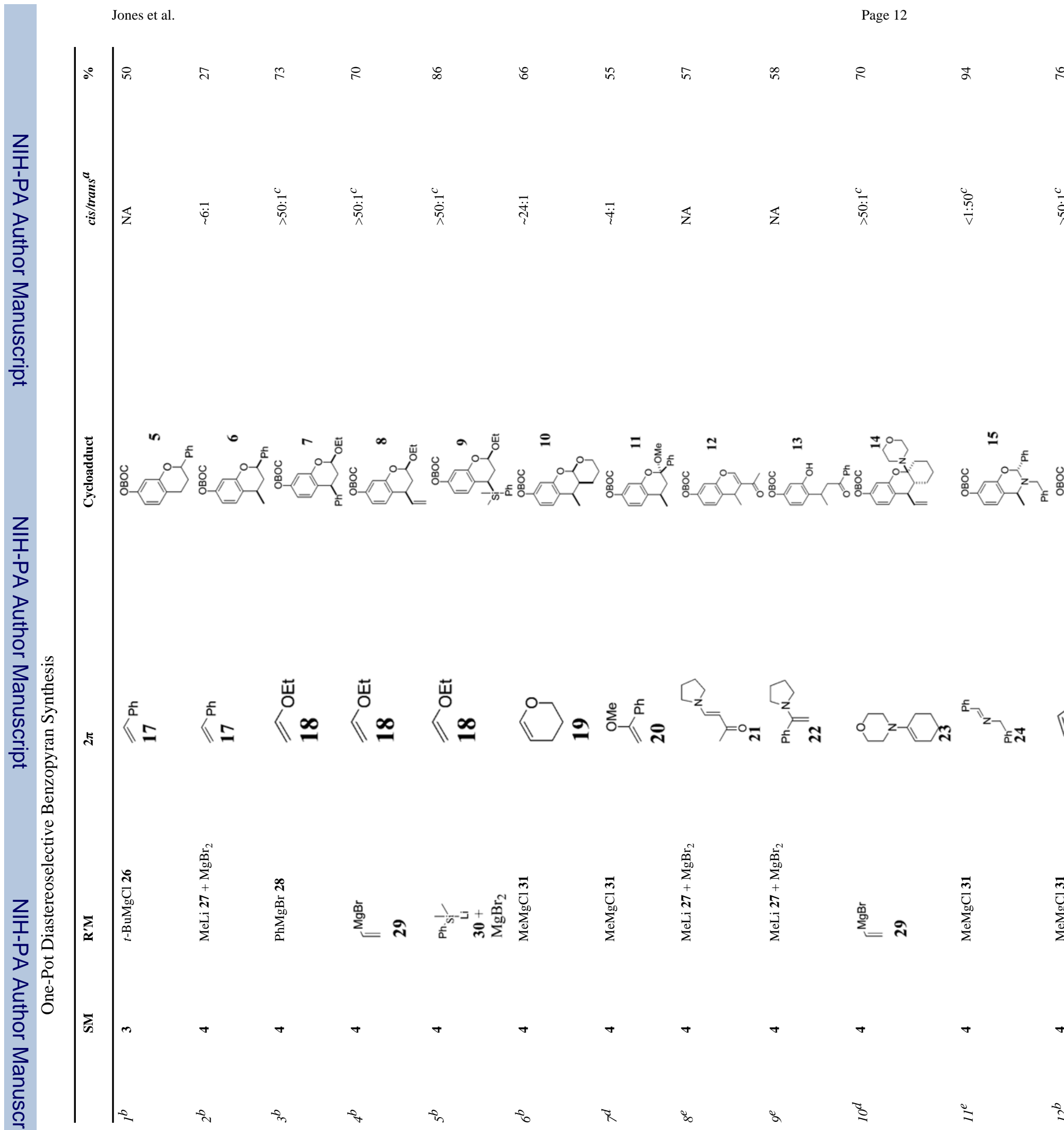

J Org Chem. Author manuscript; available in PMC 2008 June 21. 


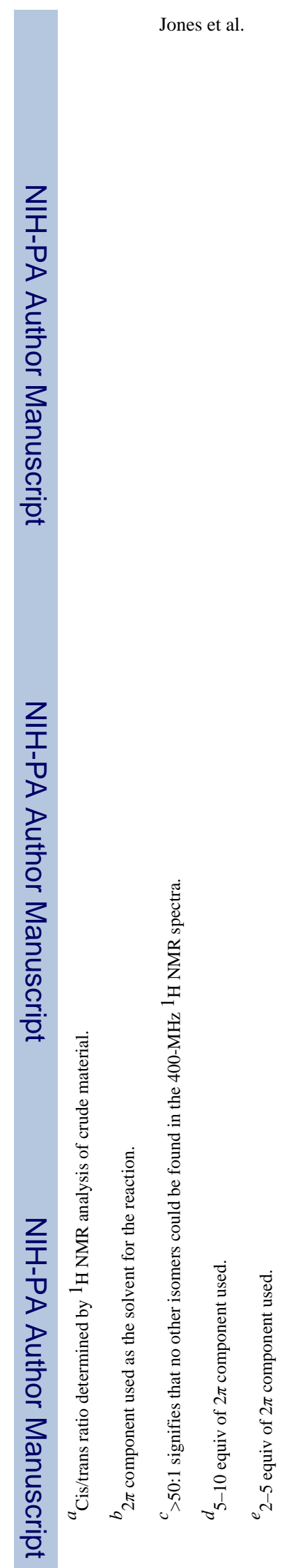

J Org Chem. Author manuscript; available in PMC 2008 June 21. 